\title{
THE INFLUENCE OF POLICY IMPLEMENTATION ON THE EFFECTIVENESS OF ACCELERATION OF ELECTRONIC ID CARD RECORDING
}

\author{
Fitriani Reyta \\ Universitas Widyatama \\ Email: fitriani.reyta@widyatama.ac.id
}

\begin{abstract}
The issue in this research is how ineffective the acceleration of electronic ID card recording is. Based on said phenomenon, the researcher suspects that the problem is influenced by policy implementation variable. Based on this issue, the proposed research question is: "How Significant the Effect of Implementation of Local Government Policy on the Effectiveness of Accelerating the Recording of Electronic ID Card is". The analysis of the research question was done using the theory of policy implementation by George C. Edwards III in Subarsono (2005: 90), based on the factors of policy implementation through the dimension of communication, resources, executor attitude and structure of bureaucracy. As for the effectiveness variable, the theoretical approach by Mahmudi (2005: 92) adapted from Steers (1985: 53) was used, consisting of the achievement of goals, integration, and adaptation. Based on the theoretical approach, the proposed hypothesis is: "The significance of the influence of the implementation of local government policy on the effectiveness of accelerating the recording of electronic ID card in District $X$ is determined by the implementation of communication, resources, executor attitude and bureaucracy structure factors". Methods used in this research are explanatory survey method, while data were collected through literature study and field study covering: questionnaire, observation, and interview. Sampling technique used is Simple Random Sampling. The data analysis technique used is linear regression analysis. Based on the result of data processing conducted, research result obtained shows a positive and significant relationship between the implementation of the policy and the Effectiveness of Acceleration of Electronic ID Card Recording in District $X$ in Bandung. Thus the hypothesis proposed in this study has been proven empirically.
\end{abstract}

Keywords : Policy Implementation, The Effectiveness of Electronic Recording.

\begin{abstract}
ABSTRAK
Masalah dalam penelitian ini adalah belum efektifnya percepatan perekaman KTP elektronik. Berdasarkan fenomena tersebut, peneliti menduga bahwa masalah tersebut dipengaruhi oleh variabel implementasi kebijakan. Berdasarkan pada permasalahan tersebut, rumusan masalah yang diajukan adalah: "Seberapa Besar Pengaruh Implementasi Kebijakan Pemerintah Daerah terhadap Efektivitas Percepatan Perekaman KTP Elektronik".Analisis masalah penelitian dilakukan dengan menggunakan teori Implementasi Kebijakan Teori George C. Edwards III dalam Subarsono, (2005:90), berdasarkan faktor-faktor implementasi kebijakan melalui dimensi komunikasi, sumber daya, sikap pelaksana dan struktur birokrasi. Adapun untuk variabel efektivitas digunakan pendekatan teori Mahmudi (2005:92) diadaptasi dari Steers (1985: 53) terdiri dari pencapaian tujuan, integrasi, dan adaptasi. Berdasarkan pendekatan teori-teori tersebut, hipotesis yang diajukan adalah: "Besarnya pengaruh implementasi kebijakan Pemerintah Daerah terhadap efektivitas percepatan perekaman KTP elektronik di Kecamatan X ditentukan oleh pelaksanaan faktor-faktor komunikasi, sumber daya, sikap pelaksana dan struktur birokrasi". Metode dalam penelitian ini adalah metode survei eksplanatif (explanatory survey method) sedangkan sumber pengumpulan data dengan menggunakan studi kepustakaan dan studi lapangan yang meliputi: angket, observasi, dan wawancara. Teknik penarikan sampel yang digunakan adalah sampel random sederhana (simple random sampling). Adapun teknik analisa data yang digunakan adalah analisis regresi liniear. Berdasarkan hasil pengolahan data yang dilakukan, diperoleh hasil penelitian yang menunjukkan adanya hubungan yang positif dan signifikan antara implementasi kebijakan terhadap efektivitas percepatan perekaman KTP elektronik di Kecamatan X di Bandung. Dengan demikian hipotesis yang diajukan di dalam penelitian ini teruji secara empirik.
\end{abstract}

Kata kunci: implementasi kebijakan, efektivitas perekaman elektronik. 


\section{Introduction}

In Indonesia in addition to changes in consumer behavior, the tight competition in retail business is also caused by the increasing number of foreign retail business entering the domestic market. Retail business from overseas is professionally managed, therefore the domestic retail business needs to be managed professionally in order to compete in serving the consumers. One strategy for an organization to compete is to build a good perception in the eyes of consumers and the public. Perception is formed from a series of information and attributes associated with information products or services can be intrinsic in nature directly related to products such as color, size, and so on. Perceptions can also be extrinsic that are not directly related to products such as brand placement, pricing, brand image, promotional services or advertising (Winsor, 1997). To get a good perception in the eyes of consumers, business people can manage one of the attributes that make up the perception that is the brand image. Brand image management aims to build a good brand, strong and unique so that a clear brand identity in the minds of consumers (Davis, 2000: 132).

The management of brand image in the growing world of small and medium retail in Indonesia today is the management of brand image through premium private brand, which is promoting house brand retailer with promotional support, not just the better quality and the cheaper price but also a good image from his promotion (Hermawan Kartajaya, 1998: 249). Having created a good brand image of the premium private label, it is expected to arise purchase interest in the minds of consumers. To create buying interest in the minds of consumers, it is also a necessary selection of the best brand name. The best brand name should imply a product benefit, imply product quality, be recognizable and memorable, specialized, and contain no negative meaning or connotation in the country or in other languages (Kotler 2003: 105).

\section{Literature Review and Hypotheses}

Presman and Wildavsky in Tachjan (2006: 24) suggested that "implementation as to carry out, accomplish, fulfill, produce, complete". Based on the statement that the implementation can be intended as an activity related to the completion of a job with the use of means (tools) to obtain results. Ripley and Franklin in Winarno (2014: 148) argued that "Implementation is what happens after a law is established that gives program authority, policy, benefits or a tangible output." Furthermore, Jones in Widodo (2010: 86) interpreted the implementation as "Getting the job done and doing it". According to Agustino (2008: 139) interpreted "Implementation is a dynamic process, where the executor of the policy conducts an activity or activity so that eventually will get a result in accordance with the goal or target policy itself. In addition, Nurdin Usman (2002: 70) expressed his opinion on the implementation or implementation as follows: "Implementation is lead to activities, actions, actions, or the existence of a system mechanism. Implementation is not just an activity, but a planned activity and for achieving the objectives of the activity ".

Understanding the implementation mentioned above, it can be said that the implementation is not just an activity, but a planned activity and done seriously based on reference norms to achieve certain objectives of the activity. Therefore, the implementation does not stand alone but is influenced by the next object. According to Guntur (2004: 39) put forward his opinion on the implementation or implementation as follows: "Implementation is the extension of activities that mutually adjust the interaction process between the objectives and actions to achieve it and require network implementers, effective bureaucracy". From the definition of implementation that has been stated above, it can be 
concluded that the implementation is a process to implement ideas, processes or a new set of activities in the hope that others can receive and make adjustments in the body of bureaucracy for the creation of a goal that can be achieved with a network of executors who can be trusted.

The essence of implementation is a series of planned and gradual activities undertaken by the implementing agency based on the policies established by the competent authorities. This is as revealed by Mazmanian and Sabatier in Agustino (2006: 153) defines the implementation of the policy as: "The implementation of basic policy decisions, usually in the form of laws, but may also be an important command or executive decisions or judicial decisions. Typically, the decision identifies the issues to be addressed, explicitly states the objectives or targets to be achieved, and various ways to structure or manage the implementation process. "According to Wiyono (2007: 137), that effectiveness is defined as an activity that is implemented and has an impact and results as expected. Based on this understanding it appears that effectiveness with respect to the results achieved in an activity or job either amount of work, quality of work or time used to complete the job. So it can be concluded that effectiveness is doing something to change it to a better and more effective in order to produce something of value and quality. Abdurrahmat (2003: 92) argues that effectiveness is the benefit of certain resources, facilities, and infrastructure that are consciously set beforehand. Based on this understanding the researcher gives the view that effectiveness is the goal set or planned by an organization by way of assessed or measured from the success rate obtained. To assess the extent to which the government organization achieved its objectives then the concept of effectiveness was used. Osborne and Gaebler (1996: 389) argue that to measure the effectiveness of government service is to be seen from the "quality of its output", how to achieve the results (quality or effectiveness of production). Thus, the concept of effectiveness is more emphasis on aspects of quality, achievement of targets that have been determined.

\section{Research Methods}

The research method used in this research is Explanatory Research Method where the data of information collected from the population, the data collected and then analyzed to measure the influence of one variable to other variables. The explanatory and crosssectional research designs, namely how the variables studied will explain the object under study and collected data and observations are made only once (Sugiono 2003: 83). All data obtained will be processed with a quantitative analysis. Source data used in this study were obtained from two data sources as follows:

1. Primary Data Source, the data obtained directly from the District X in Bandung.

2. Secondary Data Sources, ie data obtained by studying literature materials related to the issues to be discussed, whether in the form of books, applicable legislation, and other materials.

Data collection techniques in this study are used:

1. Observation, which is a technique of data collection is done by observation of the objects under study and to record the various symptoms that are considered important and related to the object of research.

2. Interview, which is a technique of data collection by asking questions and direct communication with the parties related to research problems. In this case, the researchers conducted interviews with the Sub District Official of $X$ and the communities domiciled in X Sub District. 
3. Questionnaire, the data collection technique by making a list of questions with the choice of answers that have been available in the form of multiple choice, with a view to facilitating the respondent in answering.

The population is taken by researchers from the number of officers who are in the field of control of the Department of Population and Civil Registry, officials in the District $\mathrm{X}$ and the community who live in District $\mathrm{X}$. Based on the existing population then it can be determined the samples, sampling technique to determine the sample of the Office of Population and Civil Registry as well as the Sub District Official of X, the researcher uses the saturated sampling technique (census) Sugiyono (2003: 61), i.e: saturated sampling is the sampling technique when all members of the population are used as samples. This is often done when the population is relatively small, less than 30 people. Sampling Random Sampling technique used in this research is "Simple Random Sampling" which is a technique of taking or determining samples from the random population without considering the level of strata in the population (Sugiyono, 2013: 82).

To find out whether the instrument is feasible or not to be included in the analysis, test the validity and reliability first. If declared valid and reliable, then the instrument is eligible to be included. The characteristics of the validity of the results of the correlation coefficient of product moment must be eligible if the results obtained $r$ corelation $>r$ table. With 109 (one hundred and nine) respondents who in this case use the Pearson or Product Moment statistic formula, the results obtained in accordance with the data table below:

Table 1. Validity Test Result with Bivariate Pearson (Variable X)

\begin{tabular}{|c|r|r|c|}
\hline Statement & \multicolumn{1}{c|}{$\begin{array}{c}\text { Critical } \\
\text { r Value }\end{array}$} & $\begin{array}{c}\text { R Table } \\
\text { Value }\end{array}$ & \\
\hline $\mathbf{1}$ & $\mathbf{0 , 3 5 2}$ & $\mathbf{0 , 3 0 0}$ & Valid \\
\hline $\mathbf{2}$ & $\mathbf{0 , 4 8 0}$ & $\mathbf{0 , 3 0 0}$ & Valid \\
\hline $\mathbf{3}$ & $\mathbf{0 , 7 5 3}$ & $\mathbf{0 , 3 0 0}$ & Valid \\
\hline $\mathbf{4}$ & $\mathbf{0 , 3 6 2}$ & $\mathbf{0 , 3 0 0}$ & Valid \\
\hline $\mathbf{5}$ & $\mathbf{0 , 7 5 5}$ & $\mathbf{0 , 3 0 0}$ & Valid \\
\hline $\mathbf{6}$ & $\mathbf{0 , 6 7 5}$ & $\mathbf{0 , 3 0 0}$ & Valid \\
\hline $\mathbf{7}$ & $\mathbf{0 , 7 3 9}$ & $\mathbf{0 , 3 0 0}$ & Valid \\
\hline $\mathbf{8}$ & $\mathbf{0 , 6 2 5}$ & $\mathbf{0 , 3 0 0}$ & Valid \\
\hline $\mathbf{9}$ & $\mathbf{0 , 6 7 0}$ & $\mathbf{0 , 3 0 0}$ & Valid \\
\hline $\mathbf{1 0}$ & $\mathbf{0 , 6 2 0}$ & $\mathbf{0 , 3 0 0}$ & Valid \\
\hline $\mathbf{1 1}$ & $\mathbf{0 , 6 1 0}$ & $\mathbf{0 , 3 0 0}$ & Valid \\
\hline $\mathbf{1 2}$ & $\mathbf{0 , 7 4 1}$ & $\mathbf{0 , 3 0 0}$ & Valid \\
\hline
\end{tabular}

Table 2. Validity Test Result with Bivariate Pearson (Variable Y)

\begin{tabular}{|c|c|c|c|}
\hline Statement & Critical r Value & $\begin{array}{c}\text { R Table } \\
\text { Value }\end{array}$ & Conclusion \\
\hline 1 & $\mathbf{0 , 6 1 1}$ & $\mathbf{0 , 3 0 0}$ & Valid \\
\hline 2 & $\mathbf{0 , 7 0 7}$ & $\mathbf{0 , 3 0 0}$ & Valid \\
\hline 3 & $\mathbf{0 , 8 6 5}$ & $\mathbf{0 , 3 0 0}$ & Valid \\
\hline 4 & $\mathbf{0 , 5 2 0}$ & $\mathbf{0 , 3 0 0}$ & Valid \\
\hline 5 & $\mathbf{0 , 9 2 5}$ & $\mathbf{0 , 3 0 0}$ & Valid \\
\hline
\end{tabular}




\begin{tabular}{|c|c|c|c|}
\hline $\mathbf{6}$ & $\mathbf{0 , 8 4 5}$ & $\mathbf{0 , 3 0 0}$ & Valid \\
\hline $\mathbf{7}$ & $\mathbf{0 , 8 7 0}$ & $\mathbf{0 , 3 0 0}$ & Valid \\
\hline $\mathbf{8}$ & $\mathbf{0 , 9 0 0}$ & $\mathbf{0 , 3 0 0}$ & Valid \\
\hline
\end{tabular}

Reliability testing for this study also meets the criteria of a questionnaire item is said to be reliable, the reliability of each variable is indicated by Cronbach's Alpha value greater than 0.60 (Nunnally, 1967 in Ghozali, 2005: 42). Reliability results are shown in Table 3 below:

Table 3. Reliability Test Results

\begin{tabular}{|c|c|c|c|}
\hline Variable & Critical r Value & R Table Value & Conclusion \\
\hline $\mathrm{X}$ & 0,849 & 0,300 & Strong reliability \\
\hline $\mathrm{Y}$ & 0,936 & 0,300 & Strong reliability \\
\hline
\end{tabular}

\section{Results and Discussion}

The above hypothesis will be proved by calculating the student distribution ( $\mathrm{t}$ test) which will then be compared with t-table. The result of the calculation is as follows:

$$
\begin{gathered}
t=0,805 \sqrt{\frac{109-2}{1-0,805^{2}}} \\
t=14,035
\end{gathered}
$$

The result of the calculation will be compared with t-table, where from result of distribution table $t$ with error rate equal to 0,05 resulted $t$-table equal to 1,659 . This shows that the value of $t$ arithmetic that is equal to 14.035 is greater than the value of $t$ table that is equal to 1.659 which can be described in the normal distribution curve $t$ as follows:

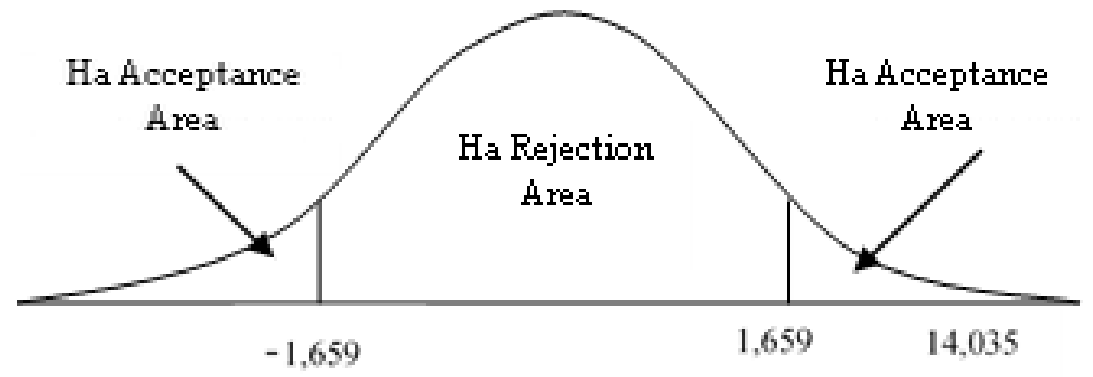

\section{Conclusion and Future Direction}

Based on the results of the study note that the relationship between Policy Implementation Effectiveness of Acceleration of Electronic ID Recording, has a relationship of 0.644 . At the test level $\alpha=0.05$ and according to the reliability classification used according to Guilford in Sugiyono, (2005: 216) this figure is in the range between $0.70-0.90$ with criteria of Strong Reliability. However how good a policy without being implemented effectively, will not produce optimal performance. Simply can be explained that the more filled elements of implementation variables Local Government Policy, the higher the effectiveness of the Acceleration of Recording of electronic ID card in District $\mathrm{X}$ in Bandung.

Based on research result of research hypothesis can be concluded that, Communication, Resource, Disposition/Attitude Executor and Bureaucratic Structure have positive and significant effect to the Effectivity of Accelerated Recording of electronic ID card in 
District $\mathrm{X}$ in Bandung. Thus the hypothesis that the researcher submitted was tested empirically, because the Policy Implementation variable had an effect on the Effectiveness of the Acceleration of the Recording of electronic ID card in X District in Bandung City through the dimension of Communication, Resources, Implementing Attitude and $\mathrm{Bu}$ reaucratic Structure. The strong influence between Policy Implementation variables and the Effectiveness of Accelerated Recording of electronic ID cards in X District, as well as the significant influence between the two variables shows that there is a change in the concept of Effectiveness of Accelerated Recording of electronic ID card in X District. In addition, the results of research indicate the existence of other significant influence largely from other variables besides Policy Implementation variables that also influence the Effectiveness of Accelerated Recording of electronic ID card in District X.

Based on the findings in this study, it is suggested to do further research by connecting variables or dimensions other than policy implementation i.e: supervision or coordination variables so that it can produce more comprehensive output and useful for the development of governmental sciences especially on the study of governance:

1. It is advisable to the Department of Population and Civil Registry to add the number of experts and staff operators.

2. It is advisable to the Department of Population and Civil Registry to add the number of the recording device.

3. It is advisable to the Department of Population and Civil Registry to add the number of blank ID stock.

4. It is advisable to the Department of Population and Civil Registry to add the number of database administrator that is 1 (one) person per District.

5. It is recommended to perform a network repair (server) to accelerate the recording of electronic ID card.

\section{References}

Abdurrahmat, Fathoni, 2003. Manajemen Sumber Daya Manusia. Bandung: Rineka.

Adi, Rianto, 2004. Metodologi Penelitian Sosial dan Hukum. Jakarta: Rajawali Pers.

Agustino, Leo, 2006. Dasar-dasar Kebijakan Publik. Bandung: Alfabeta.

Ali, Faried, 2012. Studi Kebijakan Publik. Bandung: Refika Aditama Nawawi.

Azwar, Saifuddin, 1997. Metode Penelitian. Yogyakarta: Pustaka Pelajar.

Damsar, 2011. Pengantar Sosiologi Pendidikan. Jakarta: Kencana Prenada Media.

Edward III, George C., 1980. Implementing Public Policy. Washington DC: Congressional Quarterly Press.

Grindle, Merille S., 1980. Politic and Imlementation in The Third World, Princeton New Jersey: Princeton University Press.

Guilford, James P., 1994. Fundamental Statistics in Psychology and Education. New York: Mc Graw Hill Book Company.

Guntur Setiawan, 2004. Implementasi Dalam Birokrasi Pembangunan. Bandung: Remaja Rosdakarya.

Ghozali, Imam, 2001. Aplikasi Analisis Multivariate Dengan Program SPSS. Semarang: Badan Penerbit Universitas Diponegoro.

Islamy, M. Irfan, 2000. Prinsip-prinsip Perumusan Kebijakan Negara. Jakarta: Sinar Grafika.

Kerlinger, F. N., 1998. Azas-azas Penelitian Behavioral (terjemahan). Yogyakarta: Gajah Mada University Press.

Mahmudi, 2005. Manajemen Kinerja Sektor Publik. Yogyakarta: UPP. AMP. YKPN.

Ndraha, Taliziduhu, 2003. Metodologi Ilmu Pemerintahan. Jakarta: Rineta Cipta. 
Ndraha, Taliziduhu, 2010. Metodologi Ilmu Pemerintahan. Jakarta: Rineta Cipta.

Nawawi, Zaidan, 2013. Manajemen Pemerintahan. Jakarta: Raja Grafindo Persada.

Nugroho, Riant, 2003. Public Policy, Dinamika Kebijakan-Analisis KebijakanManajemen Kebijakan. Jakarta: Penerbit PT. Elex Media Komputindo.

Nurdin, Usman, (2002). Konteks Implementasi Berbasis Kurikulum. Jakarta: PT. Raja Grafindo Persada.

Nursid, Sumaatmadja, 2006. Metodologi Pengajaran Ilmu Pengetahuan Sosial (IPS). Bandung: Alumni.

Osborne, David, and Ted Gaebler, 1992. Reinventing Government: How The Entrepreneur Spirit is Transforming The Public Service, terjemahan: Mewirausahakan Birokrasi Mentransformasikan Semangat Wirausaha ke Dalam Sektor Publik. Alih Bahasa Abdul Rosyid dan Ramelan. Jakarta: Pustaka Binaman Pressindo.

Sarwoto, 1990. Dasar-dasar Organisasi dan Manajemen, Cetakan keempat. Jakarta: Ghalia.

Setiadi, M. Elly, 2011. Pengantar Sosiologi Pemahaman Fakta dan Gejala Permasalahan Sosial. Jakarta: Kencana.

Singarimbun, Masri dan Sofian Effendi, 1995. Metode Penelitian Survei. Jakarta: LP3ES.

Steers, Richard, 1985. Efektivitas Organisasi. Terjemahan Magdalena Jamin. Jakarta: Erlangga.

Sugiyono, 2013. Metode Penelitian Kuantitatif dan Kualitatif dan Rzd. Bandung: Alfabeta.

Syafiie, Inu Kencana, 2003. Sistem Pemerintahaan Indonesia. Jakarta: Rineka Cipta.

Tachjan, 2006, Implementasi Kebijakan Publik. Bandung: AIPI-Puslit KP2W Lemlit UNPAD.

Terry, R George. 2012. Prinsip - Prinsip Manajemen. Jakarta: Bumi Aksara.

Winarno, Budi, 2004. Teori dan Proses Kebijakan Publik. Yogyakarta: Media Pressindo.

Wiyono, Bambang Budi, 2007. Metodologi Penelitian (Pendekatan Kuantitatif, Kualitatif, dan action Research). Malang: FIP Universitas Negeri Malang

Widodo, Joko, 2010. Analisis Kebijakan Publik. Malang: Bayumedia. 